\title{
Strategi pengembangan Usaha Mikro Kecil Menengah (UMKM) di Kota Malang melalui literasi informasi
}

\author{
Muhammad Shobaruddin \\ Program Studi Ilmu Perpustakaan, Universitas Brawijaya \\ Jl. M.T. Haryono No.163, Ketawanggede, Malang, Jawa Timur, Indonesia, 65145 \\ E-mail: shobar_fia@ub.ac.id
}

Received: February 2020; Accepted: September 2020; Published: December 2020

\begin{abstract}
This study examined Micro, Small, and Medium Enterprises (MSMEs) development strategies through information literacy. Information literacy can be interpreted as expertise in effectively accessing and evaluating information to solve problems and make decisions. This study aimed to improve the quality of human resources driving MSMEs in Malang through information literacy. Descriptive qualitative methods were used to describe the phenomenon as a whole. Data were collected through Focus Group Discussions (FGDs) to determine the pattern of problem identification, searching and implementing solutions, and applying information literacy to the UMKM process in Malang City. The FCD results were analyzed by identifying problems, solutions that were implemented, and information literacy application. The next step was to formulate the stages of the MSME development strategy. MSMEs in Malang City faced internal (capital, human resources, and infrastructure) and external (government support, community roles, and consumer response) constraints. The solutions implemented to overcome these obstacles have not thoroughly utilized information literacy skills, so the problem recurs. MSME development strategies that can be applied with third parties' assistance are problem identification, reflection on applied solutions, and development of information literacy skills (the ability to access information, sort and select, and understand and implement it). Based on these findings, the role of third parties, such as the government and the research team, is quite important for implementing strategies and improving the quality of MSME Human Resources.
\end{abstract}

Keywords: Information literacy; MSME; Development strategy

\begin{abstract}
Abstrak
Penelitian ini mengkaji strategi pengembangan Usaha Mikro Kecil dan Menengah (UMKM) melalui literasi informasi. Literasi informasi dapat dimaknai sebagai keahlian dalam mengakses dan mengevaluasi informasi secara efektif untuk memecahkan masalah dan membuat keputusan. Tujuan penelitian ini adalah perbaikan kualitas Sumber Daya Manusia (SDM) penggerak UMKM di Kota Malang melalui literasi informasi. Metode kualitatif deskriptif digunakan untuk dapat menggambarkan fenomena secara keseluruhan. Pengumpulan data dilakukan dengan Focus Group Discussion (FGD) guna mengetahui pola identifikasi masalah, pencarian dan penerapan solusi, serta penerapan literasi informasi dalam proses tersebut di UMKM Kota Malang. Hasil FGD dianalisis dengan tahapan identifikasi masalah, solusi yang sudah diterapkan, serta penerapan literasi informasi. Langkah berikutnya merumuskan tahapan strategi pengembangan UMKM. UMKM di Kota Malang menghadapi kendala internal (modal, SDM, dan sarana prasarana) dan eksternal (dukungan pemerintah, peran komunitas, dan respons konsumen). Solusi yang telah diterapkan untuk mengatasi kendala tersebut belum secara menyeluruh memanfaatkan kemampuan literasi informasi sehingga masalah berulang. Strategi pengembangan UMKM yang dapat diterapkan dengan bantuan pihak ketiga adalah identifikasi masalah, refleksi solusi yang sudah diterapkan, dan pengembangan kemampuan literasi informasi (kemampuan akses informasi, memilah dan memilih, serta pemahaman dan implementasinya). Berdasarkan temuan tersebut, peran pihak ketiga, seperti pemerintah maupun tim peneliti, menjadi cukup penting untuk penerapan strategi dan perbaikan kualitas Sumber Daya Manusia UMKM.
\end{abstract}

Kata Kunci: Literasi informasi; UMKM; Strategi pengembangan 


\section{PENDAHULUAN}

Sumber Daya Manusia (SDM) merupakan salah satu faktor yang memengaruhi pembangunan Indonesia. Kualitas SDM dipengaruhi beragam aspek, di antaranya sosial budaya, kesehatan, maupun pendidikan. Di level internasional, banyak proses pengukuran untuk menunjukkan kualitas SDM, salah satunya ditunjukkan dengan daya saing Indonesia. Ukkas (2017) mengatakan,

"Olehnya itu banyak daerah di Indonesia yang menitikberatkan kekuatan ekonominya pada sektor industri, terkhusus pada industri kecil. Industri kecil cenderung lebih mudah berkembang disebabkan karena tidak membutuhkan modal yang terlalu besar, teknologi yang digunakan juga relatif sederhana, dan bahan bakunya pun mudah didapatkan. Industri kecil mempunyai peranan yang sangat penting dan strategis bagi perekonomian suatu daerah, karena keberadaannya banyak memberikan manfaat dalam pengembangan ekonomi daerah."

Produktivitas sebuah negara tidak dapat terlepas dari kualitas tiap individu masyarakatnya dengan potensi yang dimiliki masing-masing. Agar potensi terus berkembang dan relevan dengan kebutuhan terkini, tiap individu harus mampu menyesuaikan diri pada perubahan. Perubahan terkini erat kaitannya dengan revolusi industri 4.0, yaitu pemanfaatan teknologi dalam kehidupan sehari-hari. Sebagaimana ditekankan dalam beberapa studi, penguasaan teknologi informasi sebagai salah satu upaya untuk pengembangan kemampuan sumber daya manusia (Muzakki, Susilo, \& Yuniarto, 2016; Indah,
2017; Yusuf, 2016).

Pendapat lain menambahkan bahwa perkembangan teknologi informasi telah membawa perubahan yang signifikan dalam hal pengadaan, organisasi, manajemen, dan penyebarluasan informasi. Banyaknya informasi yang tersedia menuntut tiap individu untuk menguasai kemampuan terkait teknologi informasi yang tidak hanya mengenai penguasaan kemampuan mengoperasikan teknologi juga mengenai literasi informasi.

Literasi informasi dapat dimaknai sebagai keahlian dalam mengakses dan mengevaluasi informasi secara efektif untuk memecahkan masalah dan membuat keputusan. Literasi informasi dipahami dengan berbeda dari berbagai sudut pandang. Literasi informasi sebagai sebuah kemampuan yang dimiliki individu untuk mengetahui kapan informasi dibutuhkan dan bagaimana cara mendapatkan informasi tersebut, mengevaluasi, dan menggunakannya secara efektif (Muntashir, 2016). Ragam informasi yang tersedia memungkinkan banyaknya jumlah dan kualitas informasi yang tidak jelas sampai pada pengguna informasi. Maka tiap individu harus dapat mengakses, memahami, memilah, dan memilih informasi sesuai manfaat dan kebutuhan. Individu yang memiliki keahlian literasi informasi dapat menggunakan informasi secara tepat dalam membuat keputusan sehingga memengaruhi perbaikan tingkat kesejahteraan.

Muntashir (2016) kembali menambahkan bahwa kategori orang yang melek informasi di antaranya, individu dapat mengenali kebutuhan informasi, mengetahui bahwa informasi yang akurat dan lengkap adalah dasar 
untuk pengambilan keputusan yang tepat, mampu mengidentifikasi sumber informasi yang potensial, mampu mengembangkan strategi pencarian informasi yang tepat, mampu mengakses sumber informasi, termasuk pemanfaatan teknologi, mampu mengevaluasi informasi, mampu mengatur informasi untuk diaplikasikan, mampu mengintegrasikan informasi baru ke dalam pengetahuan yang sudah ada pada dirinya, mampu menggunakan informasi untuk berpikir kritis dan memecahkan masalah.

Untuk itu, individu dapat memiliki dua keahlian penting yang harus dikuasai dalam mewujudkan literasi informasi, yaitu Information Technology (IT) skills dan information handling skills. Individu dalam IT skill harus menguasai, 1) keahlian dasar perangkat keras (hardware), seperti menggunakan telepon pintar (smartphone), komputer, 2) perangkat lunak (software) standar, seperti Google Chrome, Microsoft Word, 3) aplikasi jaringan (netware), seperti media sosial, dan email. Keahlian tersebut termasuk hard skill yang harus dikuasai untuk mendapatkan informasi.

Adapun individu dapat mendapatkan keahlian lain terkait information handling skills, meliputi pengetahuan dan kemampuan mengetahui sumber informasi, metode navigasi, kriteria untuk melakukan evaluasi, teknik dalam manipulasi, dan presentasi informasi. Individu yang menguasai dua keahlian tersebut maka akan dianggap mampu mendapatkan dan memberdayakan informasi dengan baik. Dengan demikian, informasi yang tersedia pun dapat dimanfaatkan secara tepat guna.

Pengetahuan literasi memiliki beberapa jenis literasi sesuai bidang keilmuan yang masih berhubungan dengan literasi informasi. Pertama, literasi digital, sebagai suatu kemampuan dalam penguasaan sumber dan perangkat digital. Kedua, literasi komputer, yaitu suatu kemampuan untuk menciptakan data, melakukan manipulasi dokumen, dan menggunakan perangkat lunak. Ketiga, literasi media, ialah suatu kemampuan dalam melakukan akses, analisis, dan produksi informasi untuk menghasilkan data yang spesifik. Keempat, literasi jaringan, adalah suatu kemampuan dalam melakukan akses informasi, menempatkan informasi, dan menggunakan informasi dalam dunia internet. Kelima, literasi gambar, sebagai suatu kemampuan untuk dapat memahami dan menggunakan gambar dalam berpikir, belajar dan mengekspresikan gambar tersebut (Agustien, Prijana, \& Yanto, 2019; Jordana, \& Suwarto, 2017; Mansyur, Rahamma, \& Fatima, 2013; Nurjanah, Rusmana, \& Yanto, 2017).

Berdasarkan beberapa sumber yang telah disebutkan, dapat disimpulkan bahwa literasi informasi mencakup beberapa keahlian. Pertama, individu mampu mencari dan menemukan informasi sesuai kebutuhan. Kedua, individu dapat mengetahui sumber daya informasi yang tersedia, seperti sarana penelusuran digital dan format informasi. Ketiga individu dapat mengetahui teknik dan pengetahuan yang diperlukan untuk mencari informasi. Keempat, individu pun dapat melakukan evaluasi dan menggunakan informasi tersebut secara tepat guna yang kemudian berpengaruh pada tingkat kesejahteraan.

Kesejahteraan dapat dipahami dari banyak sudut pandang. Berdasarkan Undang-Undang Republik Indonesia Nomor 11 Tahun 2009 Tentang 
Kesejahteraan Sosial (2009) pada pasal 1 dan 2 menjelaskan bahwa,

"Kesejahteraan sosial merupakan suatu keadaan terpenuhinya kebutuhan hidup yang layak bagi masyarakat sehingga mampu mengembangkan diri dan dapat melaksanakan fungsi sosialnya yang dapat dilakukan pemerintah, pemerintah daerah, dan masyarakat dalam bentuk pelayanan sosial yang meliputi rehabilitasi sosial, jaminan sosial, pemberdayaan sosial, dan perlindungan sosial."

Berdasarkan definisi tersebut, individu dapat berkembang apabila kebutuhan hidupnya dapat terpenuhi dan individu tersebut dapat menjalankan fungsi sosial dengan baik. Adapun tingkat sosial erat kaitannya kemampuan secara ekonomi yang berarti bahwa hidupnya sejahtera. Salah satu potensi untuk meningkatkan kesejahteraan masyarakat ialah melalui kegiatan wirausaha. "Untuk kawasan Asia-Pasifik, UKM diperkirakan menyerap sekitar 50 persen tenaga kerja yang ada" (Setiawan, 2010). Indonesia sendiri, UMKM berperan besar meningkatkan nilai ekonomi masyarakat walaupun pelaksanaannya belum optimal dan masih menghadapi sejumlah kendala, seperti kemampuan SDM yang masih sulit mengadopsi teknologi. Hal ini senada dengan data dari Rahmadani, Hakim, and Setiawati (2019) bahwa 59,2 juta pelaku UMKM di Indonesia, hanya $8 \%$ atau 3,79 juta saja yang memanfaatkan platform online dalam memasarkan produknya. Padahal pelaku usaha yang mampu mengoperasikan teknologi dapat membantu memperluas jaringan usaha, mempermudah penetrasi pasar lintas geografi, dan lain sebagainya.

UMKM memiliki kontribusi penting dan strategis dalam pembangunan ekonomi nasional (Sarfiah, Atmaja, \& Verawati, 2019). UMKM memiliki kontribusi dalam pertumbuhan ekonomi, penyerapan tenaga kerja, mendistribusikan hasil pembangunan, dan membantu masyarakat dan negara dalam menghadapi krisis.

UMKM sendiri dapat dikelompokkan dalam tiga jenis, yaitu usaha mikro dengan jumlah karyawan 10 orang, usaha kecil dengan jumlah karyawan 30 orang, dan usaha menengah dengan jumlah karyawan hingga 300 orang (LPPI \& Bank Indonesia, 2015). Secara lebih rinci, Undang-Undang Republik Indonesia Nomor 9 Tahun 1995 Tentang Usaha Kecil (1995) menyatakan bahwa usaha kecil ialah,

"Usaha yang memenuhi kriteria: memiliki kekayaan bersih paling banyak dua ratus juta rupiah, tidak termasuk tanah dan bangunan tempat usaha, atau memiliki hasil penjualan tahunan paling banyak satu miliar rupiah, milik WNI, berdiri sendiri, bukan merupakan anak perusahaan atau cabang perusahaan yang dimiliki, dikuasai atau berafiliasi baik langsung, maupun tidak langsung dengan usaha menengah atau besar, dan berbentuk usaha orang perseorangan, badan usaha yang tidak berbadan hukum, atau badan usaha yang berbadan hukum, termasuk koperasi."

UMKM sesuai perkembangannya menghadapi kendala internal, termasuk beberapa masalah SDM. Pertama, pengetahuan penggerak UMKM mengenai teknologi produksi terbaru dan cara menjalankan quality control terhadap produk yang masih kurang. Kedua, penggerak UMKM dalam membaca kebutuhan pasar masih belum tajam 
sehingga belum mampu menangkap dengan cermat kebutuhan yang diinginkan pasar. Ketiga, penggerak UMKM masih mengandalkan pemasaran produk secara sederhana dari mulut ke mulut (mouth to mouth). Penggerak UMKM belum menjadikan media sosial atau jaringan internet sebagai alat pemasaran. Padahal penggerak UMKM dari sisi kuantitas, belum dapat melibatkan lebih banyak tenaga kerja karena masih memiliki keterbatasan kemampuan menggaji. Penggerak UMKM masih sering terlibat dalam persoalan teknis sehingga mereka kurang memikirkan tujuan atau rencana strategis jangka panjang usaha.

Penggerak UMKM dalam upaya pengelolaan bisnis dapat memperhatikan beberapa faktor dan didorong terus agar mampu mendukung pengembangan bisnis UMKM secara maksimal (LPPI \& Bank Indonesia, 2015). Salah satunya adalah tenaga kerja yang masih memiliki pengetahuan, keterampilan, dan motivasi. Selain itu, tenaga kerja masih kurang disiplin, produktivitas yang rendah, dan tenaga kerja yang masih menerima upah gaji belum memadai.

Beberapa poin yang telah dijelaskan sebelumnya menggambarkan masalah yang sebenarnya dapat diatasi melalui kemampuan literasi informasi. Individu yang mampu mengoperasikan teknologi dapat mempermudah dalam memperoleh informasi. Informasi yang berlimpah dapat dimanfaatkan untuk perbaikan diri dan perbaikan usaha yang sedang dilakukan. Ragam informasi akan memberikan alternatif dalam pemecahan masalah dan pembuatan keputusan. Baik masalah secara teknis maupun pembaharuan pengetahuan sehingga peningkatan kemampuan dapat diupayakan dengan tepatnya informasi yang didapatkan dan digunakan. Terlebih lagi, masyarakat yang mampu memilah dan memilih informasi dapat memanfaatkan informasi tersebut secara tepat guna.

Sebagaimana dijelaskan sebelumnya, SDM sebagai penggerak UMKM harus memiliki kemampuan mengoperasikan teknologi dan memanfaatkan informasi tepat guna agar UMKM berkelanjutan jangka panjang. Untuk itu, penggerak UMKM harus memiliki kemampuan literasi informasi sebagai faktor penting dalam pemanfaatan informasi. Kajian empiris sebelumnya menunjukkan bahwa literasi informasi penting dalam mendukung peningkatan pendapatan UMKM. Penelitian Risnawati (2018) menunjukkan bahwa akses informasi para pelaku UMKM masih lemah pada ragam program yang disediakan pemerintah, seperti peningkatan kapasitas SDM. Selain itu, dijelaskan pula bahwa penggerak UMKM masih memiliki hambatan dalam mengakses kredit karena kurangnya informasi dan edukasi yang memadai dan adanya keterbatasan informasi mengenai perkembangan teknologi.

Selain itu, hasil penelitian Adawiyah (2011) menunjukkan keterbatasan penggerak UMKM dari segi pendidikan formal, pengetahuan, dan keterampilan yang memengaruhi manajemen pengelolaan usaha. Penelitian lain menunjukkan bahwa permasalahan yang paling mendasar dihadapi pelaku UMKM meliputi, SDM yang kurang memiliki ilmu pengetahuan dan keterampilan dalam pengembangan usaha, memiliki permasalahan dalam permodalan termasuk informasi di mana dan bagaimana cara mengaksesnya, kurangnya sarana dan prasarana, dan kurangnya akses informasi pemasaran produk (Anggraeni, Hardjanto, \& Hayat, 2013). 
Hapsari (2014) menjelaskan bahwa masalah lain yang dihadapi UMKM adalah kurangnya pengetahuan atas teknologi produksi, quality control, pemasaran, keuangan, dan akuntansi. Penelitian ini telah menunjukkan keunikannya dengan analisis mengenai kebutuhan literasi informasi dalam pengembangan UMKM.

Selain itu, ada beberapa penelitian yang menunjukkan pengaruh literasi keuangan terkait hubungan antara kemampuan literasi dan pengaruhnya pada UMKM. Penelitian pertama Aribawa (2016) mengenai pengaruh literasi keuangan terhadap kinerja dan keberlangsungan UMKM di Jawa Tengah. Penelitian kedua Rumbianingrum and Wijayangka (2018) yang meneliti mengenai pengaruh literasi keuangan terhadap pengelolaan keuangan UMKM. Berdasarkan kedua penelitian ini, banyak jenis literasi yang harus dikuasai SDM UMKM. Oleh karena itu, penelitian ini akan mengisi kesenjangan kajian keterkaitan literasi informasi dengan SDM pada UMKM.

Dengan demikian, penggerak UMKM dapat mengembangkan strategi dalam mengelola kegiatan UMKM. Strategi dirancang untuk pengembangan yang berlandaskan informasi relevan secara menyeluruh. Strategi sendiri memiliki definisi beragam, yang dapat dimaknai sebagai alat untuk mencapai tujuan. Selain itu, strategi pun dimaknai sebagai rencana tindakan yang menerangkan tentang alokasi sumber daya serta berbagai aktivitas dalam menghadapi lingkungan, memperoleh keunggulan bersaing, dan mencapai tujuan perusahaan. Salah satu caranya adalah penggerak UMKM membuat strategi berdasarkan analisis
Strength, Weakness, Opportunity, dan Threat (SWOT).

Analisis SWOT mencakup upaya dalam mengenali kekuatan, kelemahan, peluang, dan ancaman yang menentukan kinerja perusahaan. Informasi eksternal mengenai peluang dan ancaman dapat diperoleh dari banyak sumber, termasuk pelanggan, dokumen pemerintah, pemasok, kalangan perbankan, dan rekan di perusahaan lain. Banyak perusahaan menggunakan jasa lembaga pemindaian untuk memperoleh kliping surat kabar, riset di internet, dan analisis tren domestik dan global yang relevan. Irawan (2017) menyatakan bahwa untuk menganalisis secara lebih dalam tentang SWOT, maka perlu dilihat faktor internal yakni kekuatan (strength) dan kelemahan (weakness) dan faktor eksternal yaitu peluang (opportunities) dan ancaman (threats).

Maka peneliti dalam penelitian ini memiliki fokus mengidentifikasi strategi pengembangan UMKM melalui literasi informasi. Rumusan masalah yang diajukan dalam penelitian ini adalah untuk mengetahui apa saja kegiatan literasi informasi kewirausahaan berbasis Teknologi Informasi dan Komunikasi (TIK) yang telah dilakukan para penggerak UMKM dalam meningkatkan usahanya. Selain itu, penelitian ini dilakukan untuk mengetahui bagaimana strategi pengembangan literasi informasi kewirausahaan berbasis TIK yang dapat meningkatkan kompetensi UMKM dalam meningkatkan usaha dan faktor apakah yang dapat menunjang dan menghambat kegiatan UMKM. Penelitian ini memiliki tujuan menghasilkan referensi alternatif dalam rangka perbaikan kualitas SDM penggerak UMKM di Kota Malang melalui 
literasi informasi. Hal ini dilakukan melalui tahapan identifikasi masalah, proses pemecahan masalah, level adopsi teknologi, dan tingkat literasi informasi.

\section{METODE PENELITIAN}

Penelitian ini menggunakan metode kualitatif deskriptif. Metode pengumpulan data yang digunakan adalah kualitatif, yaitu mengumpulkan data dalam bentuk kata-kata dan gambar. Penelitian deskriptif sendiri dijelaskan Neuman (2013), sebagai teknik menyajikan gambaran detail spesifik dari situasi, latar sosial, atau hubungan. Secara lebih rinci, dijelaskan bahwa penelitian deskriptif memberikan gambaran yang terperinci, sangat akurat. Di mana data baru bertentangan dengan data sebelumnya. Data ialah seperangkat kategori yang dapat diklasifikasikan jenisnya. Selain itu, penelitian deskriptif memperjelas urutan langkah atau tahapan penelitian, mendokumentasikan proses atau mekanisme sebab-akibat, dan melaporkan latar belakang atau konteks situasi.

Metode penelitian kualitatif deskriptif digunakan untuk menggambarkan secara detail dan menyeluruh dalam proses identifikasi kemampuan literasi SDM UMKM di Kota Malang. Hal ini menunjukkan mengenai bagaimana keterkaitan situasi, latar sosial, atau hubungan yang memengaruhi kualitas SDM. Berdasarkan proses di atas, tahap selanjutnya adalah merancang strategi pengembangan UMKM berbasis literasi informasi.

Untuk menjawab masalah penelitian (gambar 1), peneliti melakukan identifikasi UMKM di Kota Malang dan mengenali profil Sumber Daya Manusia (SDM) dengan syarat masih aktif secara produksi dan penjualan. Peneliti dalam menentukan kriteria informan menggunakan purposive sampling sebagai, "A valuable sampling type for special situations. It is used in exploratory research or in field research. It uses the judgment of an expert in selecting cases, or it selects cases with a specific purpose in mind. (Neuman, 2014). Purposive sampling dikatakan sebagai teknik pengambilan informan yang berdasarkan kriteria tertentu. Adapun peneliti dalam penelitian ini memilih informan yaitu SDM UMKM yang masih aktif mengeluarkan produk dan aktif berkegiatan dalam pengembangan produk.

Selain itu, peneliti dalam mencari data penelitian menggunakan sumber dokumen mengenai data usaha mikro dan makro yang berfokus menjual produk dari Dinas Koperasi dan Usaha Mikro Kota Malang. Setelah data terkumpul, peneliti menyeleksi daftar penggerak UMKM berjumlah 7 UMKM yang diundang melakukan Focus Group Discussion (FGD). Adapun peserta FGD ialah pemilik dan karyawan yang sudah bekerja minimal tiga tahun. Peneliti melakukan FGD untuk melihat pola pemecahan masalah, pembuatan keputusan, penggunaan teknologi dan proses literasi informasi yang sehari-hari dilakukan saat bekerja, dan roadmap pemenuhan kebutuhan pengetahuan, informasi dan keterampilan.

Kemudian, peneliti secara berkala mengadakan pelatihan literasi Informasi dan pengembangan hasil pelatihan dilakukan di tiap UMKM. Peneliti kemudian melakukan proses evaluasi dari data yang terkumpul, melalui analisis dan kategorisasi data untuk kebutuhan proses desain strategi literasi informasi. Proses evaluasi dilakukan selama Oktober hingga Desember 2019. Adapun lokasi penelitian dilakukan di Kota Malang dengan jumlah UMKM sebanyak 536. Jumlahnya begitu 
besar namun masih terdapat kesenjangan produktivitas yang cukup tinggi. Maka berdasarkan hasil wawancara saat tahap pra penelitian menunjukkan bahwa kualitas SDM memengaruhi keberlangsungan UMKM tersebut.

\section{HASIL DAN PEMBAHASAN}

Pada bagian hasil dan pembahasan merupakan hasil analisis dari FGD, observasi, dan wawancara dengan Dinas UMKM di Kota Malang. Peneliti lalu melakukan pemetaan dari hasil analis untuk menjawab rumusan masalah. Peneliti telah melakukan analisis mengenai kendala yang dialami UMKM Kota Malang, yakni kendala internal berupa modal, sumber daya manusia, dan sarana prasarana, dan kendala eksternal UMKM. Kemudian peneliti mengamati UMKM dalam melakukan penyelesaian masalah. Berdasarkan hal ini, maka peneliti membuat model strategi pengembangan UMKM menggunakan literasi informasi adaptasi dari kendala yang dimiliki UMKM dan penyelesaian masalahnya. Peneliti mengilustrasikan hal ini dalam gambar 1 dan gambar 2 .

Permasalahan internal pertama yaitu modal. Masalah ini merupakan salah satu masalah yang masih dihadapi pengusaha karena kebanyakan pengusaha tersebut menggunakan modal pribadi. Hasil temuan di lapangan, penggerak UMKM memiliki beberapa pilihan sumber modal, di antaranya bersumber dari kompetisi wirausaha, pemerintah, dan lembaga keuangan (bank).

Namun informasi sumber pilihan modal di atas belum sampai pada Penggerak UMKM sehingga beberapa penggerak UMKM yang membutuhkan informasi tersebut masih dililit kendala modal. Selain itu, informasi sumber modal pun sebenarnya terdapat di dinas terkait dan komunitas. Namun, tidak semua UMKM secara aktif melakukan koordinasi dengan dinas maupun komunitas.

Salah satu hal yang menarik adalah komunitas berperan sebagai perantara antara UMKM dengan lembaga pemberi modal atas faktor kepercayaan. Salah satu aspek pertimbangan lembaga tersebut adalah kebersamaan dalam komunitas. Secara positif, syarat yang biasanya tergolong rumit bagi UMKM berubah sederhana dengan perantara komunitas. Namun, kesempatan ini belum didapatkan semua komunitas secara merata karena alur informasi yang belum jelas.

Selain itu, penggerak UMKM pun belum dapat mengelola dana modal secara baik sehingga informasi pengelolaan arus dana yang baik masih banyak diperlukan penggerak UMKM. Pengelolaan dana diperlukan untuk kegiatan keseharian, riset dan inovasi sebagai upaya pengembangan usaha selanjutnya. Hal ini terkait kualitas SDM pengelolaan keuangan, tenaga kerja, pemasaran, dan lain sebagainya.

Permasalahan internal kedua yakni SDM yang kurang memadai dalam segi keterampilan, pembagian kinerja, dan jumlah. Mayoritas usaha yang didirikan melalui perencanaan yang kurang matang, seperti penyusunan pembagian kerja dan karyawan yang masih berasal dari keluarga dan kerabat. Karyawan tersebut jumlahnya tidak lebih dari lima orang yang statusnya bukan pegawai tetap. Jumlah karyawan ini sebenarnya bisa maksimal apabila terdapat jam kerja yang efektif digunakan dan ada target kerja yang harus dipenuhi. Namun seringkali karyawan dari keluarga membuat aturan tidak efektif karena rasa sungkan sehingga profesionalitas sulit dipraktikkan. Adapun 
jumlah karyawan yang terbatas masih terpaut kendala apabila permintaan produksi banyak.

Karyawan dari anggota keluarga ketika performa kerja tidak sesuai standar kualitas maka memunculkan kendala. Adapula karyawan yang membawa pulang pekerjaan dapat mengakibatkan tidak bisa dipastikannya proses produksi. Karyawan yang bekerja di tempat kerja akan dikontrol penggerak UMKM dalam proses produksi sehingga kesalahan dapat diketahui dan dikurangi. Selain itu, karyawan yang bekerja di tempat kerja dapat mengurangi gangguan yang mungkin muncul ketika bekerja di rumah, seperti aktivitas membersihkan rumah atau bersantai.

Kendala lainnya ialah pemasaran dan keuangan yang termasuk ke dalam keterampilan. Ada beberapa penggerak UMKM memang sudah menerapkan dan mulai memasarkan produk menggunakan teknologi dan internet, contohnya sosial media Instagram dan Facebook. Kedua media sosial tersebut mudah dipelajari dan dapat dioperasikan secara sederhana menggunakan telepon pintar (smartphone). Namun belum semua penggerak UMKM menemukan cara yang tepat dalam memasarkan produk. Sebagian penggerak UMKM menyatakan bahwa kegiatan langsung berupa pameran sangat membantu UMKM bertemu dengan pasar baru, tetapi seringkali harga sewa tempat sangat mahal sehingga UMKM tidak mampu berpartisipasi.

Ketika pameran diadakan dinas, penggerak UMKM harus menjalin komunikasi dengan komunitas agar UMKM yang dipilih tidak terbatas. Komunitas memegang peranan penting dalam perkembangan suatu UMKM. Komunitas sangat mengetahui kapasitas
UMKM anggota. Hal ini membuat penyelenggara pameran selalu mencari informasi mengenai kriteria atau syarat UMKM sebagai bagian dari pameran. Maka, UMKM dapat diberikan kesempatan dan arahan agar sesuai kriteria yang diminta untuk pameran.

Selain itu, penggerak UMKM pun harus memperhatikan media pemasaran yang digunakan untuk mengenalkan produk. Penggerak UMKM harus mengetahui terlebih dahulu konsumen yang tepat sehingga media yang dipilih dapat tetap sasaran. Adapun penggerak UMKM pun dapat merancang pengemasan produk yang menarik, mengenal pilihan pemasaran yang dapat dilakukan, dan inovasi yang diperlukan. Maka, penggerak UMKM setelah mengenal konsumen dan media pemasaran yang akan digunakan dalam pemasaran produk akan meningkatkan nilai penjualan produk dan meluaskan jejaring.

Selama ini, penggerak UMKM masih mengalami kesulitan dalam menyesuaikan produk untuk sesuai target pasar. Hal ini berakibat produksi yang ada akan menumpuk karena tidak dapat didistribusikan dengan baik. Selain itu, nilai pemasukan pun akan berkurang, membuat siklus bisnis terhenti, dan kelangsungan hidup UMKM dipertaruhkan.

Permasalahan internal ketiga ialah sarana prasarana, misalnya teknologi yang digunakan dalam kegiatan produksi. Penggerak UMKM sebagian besar masih memanfaatkan mesin yang sederhana. Hal ini tentu berbeda dengan usaha level besar yang memanfaatkan mesin canggih. Sisi positifnya, penggerak UMKM dapat melayani pesanan satuan (custom) yang jarang bisa dilakukan pabrik atau usaha 
skala besar. Adapun kekurangannya, UMKM tidak dapat melakukan produksi dengan cepat dan hasilnya tidak sebagus produksi usaha skala besar. Dengan demikian, bagi usaha skala kecil harus dapat mengembangkan keahlian SDM melalui pendidikan non formal agar keterampilan penggunaan mesin produksi bagus.

Penggerak UMKM selain mengalami masalah internal, mereka pun menghadapi masalah eksternal yang terdiri dari pemerintah, komunitas, dan respons konsumen. Masalah eksternal pertama, pemerintah sebagai salah satu pihak yang diharapkan mendukung pengembangan UMKM. Pemerintah sebagai sumber informasi dalam menjalankan program pemerintah. Dinas UMKM di Kota Malang memiliki beberapa program, di antaranya "Klinik Usaha Mikro" yang memberikan sesi pelatihan dengan topik berbeda untuk mengakomodasi kebutuhan UMKM. Namun pelatihan tersebut sebatas materi atau pengetahuan saja, tidak mengajak penggerak UMKM praktik sehingga penggerak UMKM masih mengalami kesulitan dalam mengimplementasikan pengetahuan yang diberikan. Selain itu, pelatihan tidak memberikan indikator keberhasilan dan kekhususan pengembangan produk usaha sendiri. Maka, pelatihan dari pemerintah belum secara signifikan memiliki dampak dalam perkembangan UMKM.

Masalah eksternal kedua ialah komunitas belum mendapatkan solusi dalam mengembangkan UMKM Kota Malang. Keberadaan komunitas memang cukup banyak dan beragam di Kota Malang. Komunitas berdiri ada yang merupakan hasil binaan dinas atau inisiatif UMKM sendiri. Komunitas binaan dinas memiliki karakteristik merupakan produsen dan hanya satu keanggotaan komunitas binaan, tidak boleh dualism sedangkan komunitas dari UMKM terbuka untuk diikuti.

Komunitas bagi penggerak UMKM berfungsi sebagai penghubung informasi dari pihak dinas ke UMKM maupun sebaliknya. Informasi yang disebarkan dapat berupa pelatihan, Hubungan Kerja sama Secara Lembaga atau Business to Business (B2B), pengembangan misi dagang, atau kesempatan mendapatkan modal dana. Komunitas memiliki informasi yang lengkap mengenai penggerak UMKM. Hal ini memudahkan pihak dinas tanpa harus menghubungi satu persatu untuk mendapatkan informasi mengenai UMKM sesuai kriteria yang dibutuhkan sehingga dinas dapat melakukan kerja secara efisien dengan hasil yang diinginkan. Selain itu, dinas pun memperbaiki diri dengan membuka media komunikasi yang lebih beragam. Dengan demikian, UMKM dapat langsung terhubung dengan pihak dinas dan mendapatkan informasi sesuai yang dibutuhkan.

Walaupun demikian, komunitas masih memiliki beberapa kelemahan. Komunitas terkadang tidak dapat memastikan bahwa semua penggerak UMKM adalah produsen, khususnya komunitas binaan dinas. Ada penggerak UMKM yang lebih memilih menjual barang produksi dari pihak lain (reseller) dan tidak fokus pada satu produk atau jasa yang ingin dikembangkan sehingga UMKM lain merasa terganggu. Adapun anggota dalam satu komunitas dapat berasal dari pengrajin. Namun, produk yang dihasilkan beragam sehingga informasi yang dapat dibagikan kurang beragam. Selain itu, komunitas masih memiliki kendala komunikasi karena 
kesamaan yang minim antar satu UMKM dengan yang lain dalam satu komunitas.

Masalah eksternal ketiga ialah respons konsumen yang kurang sesuai. UMKM masih kesulitan merespons kebutuhan konsumen yang seringkali sulit dipenuhi, contohnya permintaan bahan yang sulit terpenuhi karena produksi produk UMKM masih dalam jumlah kecil dan belum tersedia stok bahan baku yang cukup banyak. Selain itu, penggerak UMKM menyediakan produk produksi yang baru sedangkan konsumen lebih tertarik melakukan reparasi terhadap produk yang dimiliki konsumen. Konsumen memilih reparasi karena biaya relatif lebih rendah dan konsumen pun jarang komplain. Hal ini membantu penggerak UMKM menekan biaya produksi dan tidak memerlukan bahan baku yang terlalu sulit untuk dibeli.

Adapun penggerak UMKM Kota Malang masih memiliki kendala dari dalam dan luar dalam mempraktikkan aktivitas literasi informasi, contohnya dalam pemanfaatan pencarian informasi dan sosial media secara umum. Maka penggerak UMKM memerlukan pengembangan keahlian mencari dan menggunakan informasi agar informasi yang didapatkan lebih tepat guna. Sebagaimana ditekankan dalam beberapa penelitian, penguasaan teknologi informasi sebagai salah satu upaya untuk mengembangkan kemampuan sumber daya manusia (Indah, 2017; Muzakki et al., 2016; Yusuf, 2016). Permasalahan pun mengerucut pada desain produk, proses produksi, dan pemasaran produk.

Berdasarkan hasil analisis permasalahan dan upaya yang telah dilakukan penggerak UMKM, ada beberapa strategi yang dapat diimplementasikan sesuai adaptasi atas faktor internal dan eksternal. Secara singkat, terdapat beberapa faktor internal yang perlu dipertimbangkan. Pertama, penggerak UMKM masih kekurangan modal karena akses informasi mengenai modal masih kurang. Selain itu, penggerak UMKM pun masih kurang pengetahuan dalam pemanfaatan modal. Kedua, SDM terampil diperlukan dalam pengelolaan produk UMKM yang tepat. Karyawan yang berasal dari keluarga atau non keluarga akan mendapatkan peran, hak dan kewajiban yang dibagi secara profesional. Ketiga, penggerak UMKM dapat melengkapi sarana prasarana produksi melalui teknologi untuk mempermudah produksi yang memengaruhi jumlah produksi.

Adapun faktor eksternal bersumber dari penggerak UMKM sendiri. Pertama, pemerintah dirasakan belum optimal mengembangkan UMKM Kota Malang padahal pemerintah sebagai tempat bersandar masyarakat. Pemerintah dalam membuat program pelayanan bagi penggerak UMKM belum sesuai dengan kebutuhan masyarakat. Faktor eksternal kedua dari komunitas. Komunitas sebagai mediator penggerak UMKM dengan pemerintah dan diharapkan dapat memberikan manfaat yang optimal bagi penggerak UMKM. Namun penggerak UMUM masih merasakan adanya kesenjangan kesempatan dan kualitas UMKM yang ada masih perlu diperbaiki.

Faktor eksternal ketiga adalah respons konsumen. Konsumen memiliki kebutuhan yang beragam di Indonesia yang membuat kendala tersendiri yang cukup menantang, misalnya faktor ekonomi, kesukaan, kualitas, dan lain sebagainya yang memengaruhi perkembangan UMKM. Kesimpulannya, faktor eksternal dan internal di atas 
memiliki fokus pada desain produk, proses produksi, dan pemasaran produk. Maka dibutuhkan perumusan strategi yang dapat diimplementasikan dalam pengembangan UMKM lain di Indonesia.

Penggerak UMKM sebagai SDM harus melek informasi. Hal ini dikenali melalui beberapa atribut di antaranya, SDM dapat mengenali kebutuhan informasi, mengetahui bahwa informasi yang akurat dan lengkap adalah dasar dalam pengambilan keputusan yang tepat, mampu mengidentifikasi sumber informasi yang potensial, mampu mengembangkan strategi pencarian informasi yang tepat, dan mampu mengakses sumber informasi termasuk pemanfaatan teknologi. Kemudian SDM UMKM harus dapat mengevaluasi informasi, mampu mengatur informasi untuk diaplikasikan, mampu mengintegrasikan informasi baru ke dalam pengetahuan yang sudah ada pada dirinya, dan mampu menggunakan informasi dalam pemikiran kritis dan pemecahan masalah (Muntashir, 2016).

Pada gambar 2, terlihat model strategi pengembangan UMKM menggunakan literasi informasi sebagai hasil analisis data penelitian. Model tersebut menunjukkan tahapan yang sebaiknya diterapkan satu persatu melalui bimbingan pihak ketiga terkait pemanfaatan teknologi dan literasi informasi. Berdasarkan penerapan yang baik, maka akan tampak kekurangan dan kendala lain yang mungkin dihadapi UMKM dalam proses pengembangan usaha. Dengan demikian, pelaku usaha UMKM diharapkan dapat memahami kelebihan dan kekurangan dalam siklus kerja harian sehingga UMKM dapat melakukan pengembangan diri secara mandiri di masa yang akan datang.
Strategi pengembangan UMKM pada tahap awal dilakukannya identifikasi masalah UMKM. Hal ini bertujuan agar informasi yang dicari dapat sesuai dengan masalah yang dihadapi dan meminimalkan masalah satu persatu. Masalah dilakukan identifikasi dari tiap aspek, misalnya dari SDM, produksi, distribusi, quality control, dan lainnya. Tahap identifikasi dilakukan dalam bentuk diskusi secara individu atau kelompok melalui suasana formal atau non formal. Diskusi secara berkelompok melalui FGD dan individu melalui wawancara. Sesuai keragaman aspek dan metode yang dilakukan maka akan memperkaya data tentang masalah yang mungkin belum terdeteksi.

Penggerak UMKM dalam menghadapi masalah faktor internal dan eksternal telah mencoba mengimplementasikan solusi untuk mengatasi masalah tersebut. Namun, pelaksanaannya sendiri belum maksimal karena masih ada kendala saat penerapan solusi. Kendala ini dapat memunculkan masalah lain yang dihadapi UMKM tersebut. Maka diperlukan proses penyelesaian masalah secara detail harapannya agar dapat memperbesar persentase solusi tepat guna bagi pengembangan usaha.

Penggerak UMKM dalam menerapkan solusi atas permasalahan yang dihadapi dapat memanfaatkan teknologi sebagai pencarian informasi, seperti memperhatikan bentuk teknologi yang digunakan di antaranya smartphone, komputer, atau media yang dituju menggunakan search engine, media sosial, dan penggunaan kata kunci dalam pencarian informasi. Informasi sebagai bentuk awal dari alternatif solusi yang dapat diimplementasikan para penggerak UMKM. Ketika penggerak UMKM 
mendapatkan informasi yang dibutuhkan, maka penguasaan keahlian mengoperasikan teknologi harus dipersiapkan. Sebagaimana dijelaskan sebelumnya bahwa pembelajaran literasi informasi juga beriringan dengan literasi lain yaitu literasi digital, literasi komputer, literasi media, literasi jaringan, dan literasi gambar (Agustien et al., 2019; Jordana \& Suwarto, 2017; Mansyur et al., 2013; Nurjanah et al., 2017).

Masyarakat Indonesia sendiri hampir memiliki smartphone, yang digunakan untuk mencari informasi melalui mesin pencari (search engine) dan media sosial. Sebagian besar orang menggunakan media sosial YouTube, Instagram, dan Facebook. Media sosial memiliki penampilan yang lebih menarik di mana bentuk informasi yang disajikan dalam bentuk visual dan audio visual. Media sosial memberikan informasi yang dibutuhkan masyarakat dan memberikan hiburan. Media sosial lebih mudah digunakan dibandingkan mesin pencari yang memberikan informasi pertama yang disediakan dalam bentuk teks (kata-kata). Tidak semua orang memiliki kemampuan membaca semua informasi dalam bentuk kata-kata secara merinci sehingga orang ketika membaca dapat merasa bosan dengan cepat.

Sumber informasi yang melimpah tidak serta merta membantu penggerak UMKM dalam menemukan informasi yang tepat. Maka penggerak UMKM perlu memiliki kemampuan literasi informasi. Sesuai gambar 2, penggerak UMKM perlu menguasai tiga kemampuan, di antaranya kemampuan penggunaan teknologi dalam mengakses informasi, kemampuan mencari, memilah, memilih informasi agar tepat guna, dan sesuai kemampuan dalam implementasi informasi.

Tahap pertama penggerak UMKM harus mampu menggunakan teknologi untuk mengakses informasi. Penggerak UMKM harus menguasai dan memastikan jenis media dan teknologi yang akan digunakan. Hal dilakukan agar penggerak UMKM dapat mengenal kecenderungan atau pola pelaku usaha saat mengakses informasi. Preferensi media akan meningkatkan keberhasilan peningkatan kemampuan terkait. Walaupun demikian, berbagai media pun harus tetap dipelajari. Kemampuan ini harus dimaksimalkan untuk memperluas penggunaan teknologi dalam peningkatan produktivitas pelaku usaha.

Tahap kedua, penggerak UMKM harus mampu mencari, memilah, dan memilih informasi agar tepat guna. Kemampuan mencari informasi terkait strategi menemukan informasi yang dibutuhkan dengan menggunakan kata kunci tertentu. Kata kunci merupakan gambaran dari kata-kata penting atau utama yang berhubungan dengan kebutuhan informasi. Selain kata-kata, dapat disertakan juga tanda baca, misalkan tanda petik, tanda tambah, tanda garis bawah, dan lain sebagainya. Hal tersebut tampak sederhana namun dapat menghemat waktu dalam mendapatkan hasil pencarian informasi, contohnya tanda petik yang berfungsi menyaring informasi sesuai kata kunci dan fokus pada subyek tertentu. Apabila saat pencarian informasi tidak menggunakan simbol pencarian informasi maka semua informasi yang tidak dibutuhkan akan muncul sehingga menghabiskan banyak waktu.

Penggerak UMKM setelah mendapatkan alternatif informasi, maka kegiatan selanjutnya memilah informasi melalui membaca informasi tersebut satu persatu. Setelah itu, penggerak UMKM 
melakukan kategorisasi informasi yang dapat digunakan sesuai masalah yang dihadapi. Hal ini dilakukan untuk memudahkan penggerak UMKM ketika akan menggunakan kembali informasi tersebut sehingga dapat menghemat waktu pencarian informasi di kemudian hari.

Informasi yang telah dilakukan kategorisasi kemudian dipilih mana yang prioritas. Pada tahap ini, informasi yang telah didapatkan ditentukan apakah dapat diimplementasikan atau ada aspek lain yang dipertimbangkan sebelum menggunakan informasi. Semua proses tersebut akan dilakukan dalam pemanfaatan informasi agar lebih tepat guna. Selain itu, penggerak UMKM dapat lebih teliti menganalisis informasi yang didapatkan agar kebutuhan informasi di masa akan mendatang memiliki dokumentasi yang baik.

Tahap ketiga, penggerak UMKM memiliki keahlian dalam mengimplementasikan informasi. Pemahaman informasi yang tepat akan memengaruhi cara implementasi informasi, termasuk pencarian informasi, kategorisasi, dan lain sebagainya. Maka tingkat keberhasilan implementasi informasi pun ditentukan kemampuan ini. Ketika proses implementasi informasi, perlu pengamatan seksama oleh atasan atau pihak ketiga agar dipastikan pelaksanaannya tepat. Apabila penerjemahan informasi belum sesuai maka akan terdapat kendala dalam pengembangan potensi sumber daya manusia dan produktivitas usaha.

Peningkatan kemampuan penggerak UMKM dalam mengimplementasikan informasi akan memengaruhi peningkatan kemampuan pengambilan keputusan. Pada proses sebelumnya, merupakan tahapan yang membantu dalam penentuan solusi pemecahan masalah yang dihadapi. Penggerak UMKM dalam proses implementasi informasi akan memperoleh solusi yang berulang kemudian terhenti jika manfaat telah dirasakan. Selanjutnya, penggerak UMKM akan memutuskan solusi yang memiliki dampak atau sesuai kebutuhan dan perlu adanya aktivitas dalam menjaga kualitas tiap performa kinerja.

Dengan demikian, solusi yang ditemukan penggerak UMKM akan memengaruhi kinerja produksi secara positif, contohnya desain produk, proses produksi, dan pemasaran produk. Berdasarkan analisis masalah yang dihadapi UMKM Kota Malang, pertama terkait desain produk. Desain produk sebagai salah satu kunci untuk menarik perhatian konsumen sehingga penggerak UMKM dapat mengetahui preferensi konsumen dan menyesuaikan diri secara berkala. Proses yang dijelaskan sebelumnya pun dapat digunakan dalam tahap ini.

Penggerak UMKM dapat mengetahui preferensi konsumen dengan memanfaatkan teknologi, seperti mencari hasil survei yang telah dilakukan orang lain secara daring. Adapun informasi lainnya berasal dari hasil penelitian dan observasi jenis usaha yang menghasilkan produk serupa. Sesuai data dari Dinas UMKM Kota Malang, UMKM yang terdaftar berjumlah 536. Sebelumnya tiap UMKM harus mengisi informasi nama UMKM, jenis usaha, nama merek, dan alamat UMKM. Namun ada beberapa UMKM yang belum mencantumkan informasi secara jelas mengenai jenis usaha yang sedang dikerjakan. Maka peneliti mengklasifikasikan data UMKM ini sesuai jenis usaha yang terdaftar dan 
didapatkan data 492 UMKM dari jumlah awal 536 UMKM. Pada tabel 1 terlihat bahwa klasifikasi UMKM Kota Malang terdiri dari usaha pakaian, makanan (produk), makanan (kuliner) dan katering, minuman, kriya dan kerajianan, jasa, toko/berjualan, perkebunan dan tanaman. Selain itu, peneliti untuk mengetahui jenis usaha dari tiap UMKM telah melakukan observasi dengan mendatangi kegiatan klinik bisnis yang diadakan Dinas UMKM Kota Malang. Kegiatan ini berisi pembahasan mengenai perkembangan preferensi konsumen sesuai jenis usaha dan perkembangan teknologi. Adapun jenis usaha yang memiliki produk serupa berarti preferensi konsumen telah disesuaikan dengan target usaha.

Tabel 1

Kategori UMKM Dinas UMKM Kota Malang

\begin{tabular}{lll}
\hline No & Kategori UMKM & Jumlah \\
\hline 1 & Pakaian & 48 \\
2 & Makanan (produk) & 160 \\
3 & Makanan (kuliner) \& & 45 \\
& katering & \\
4 & Minuman & 28 \\
5 & Kriya \& kerajianan & 133 \\
6 & Jasa & 51 \\
7 & Toko/berjualan & 23 \\
8 & Perkebunan \& tanaman & 4 \\
& Total & 492 \\
\hline
\end{tabular}

Sumber: Hasil analisis penelitian, 2019

\section{Penggerak UMKM dapat} menggunakan semua metode tersebut dan membandingkan hasil informasinya satu sama lain. Desain produk yang telah diputuskan lalu dilakukan replikasi, dilakukan uji coba, dan survei ulang untuk mengetahui respons konsumen. Hal ini dilakukan agar perubahan yang dilakukan tidak gegabah dan sumber daya yang terpakai secara efektif dan efisien.

Kemudian analisis masalah kedua ialah peningkatan kinerja yang berkaitan dengan proses produksi. Proses produksi memiliki tingkat kesulitan yang berbeda antara satu jenis usaha dengan yang lain. Penggerak UMKM dalam peningkatan kinerja perlu menyisihkan sumber daya tersendiri. Penggerak UMKM dalam jangka pendek akan mengeluarkan sumber daya yang lebih banyak namun hal ini akan menguntungkan dalam jangka panjang seiring perbaikan performa kinerja. Perbaikan performa kerja akan memengaruhi peningkatan produksi dari segi kuantitas dan kualitas. Untuk itu, penggerak UMKM harus melakukan sistem quality control secara berkala agar kualitas kerja dapat terjaga baik.

Analisis masalah ketiga mengenai peningkatan kinerja yaitu pemasaran produk. Banyak penggerak UMKM dalam proses produksi dan desain produk sudah baik namun masih memiliki kekurangan pengetahuan dalam pemasaran produk. Hal ini mengakibatkan penimbunan produk sehingga membuat macet perputaran dana dan proses lainnya. Penggerak UMKM sebenarnya sudah mengetahui mengenai pengetahuan pemasaran produk, di mana mereka dapat memanfaatkan promosi secara luring dan daring. Beberapa penggerak UMKM mencoba memanfaatkan media daring namun tanpa promosi secara berkala sehingga hasilnya masih kurang maksimal. Di sisi lain, bentuk dan media promosi secara daring kurang diketahui dan dikuasai dengan baik. Selain itu, pemilik usaha tidak cukup tertarik untuk memanfaatkan teknologi sebagai media promosi. Padahal, banyak informasi yang dibutuhkan tergantung kondisi dan motivasi pelaku usaha.

\section{Penggerak}

UMKM

ketika memasarkan produk harus memahami promosi daring dan luring. Kedua 
promosi ini perlu diketahui dan dimanfaatkan penggerak UMKM. Bentuk promosi luring dapat dilakukan mulai dari door to door, membuka toko, mengikuti komunitas, mengikuti acara, dan mengikuti kegiatan bazar dan pameran. Semua kegiatan ini memiliki karakteristik dan strategi tersendiri. Penggerak UMKM dengan mengetahui informasi mengenai karakteristik tiap media promosi maka akan terbantu dalam melakukan identifikasi kesesuaian usaha dengan media promosi tersebut. Dengan demikian, penggerak UMKM dapat mengupayakan metode pemasaran yang tepat sesuai karakter usaha.

Tiap penggerak UMKM yang telah mengimplementasikan strategi solusi dapat menyelesaikan masalah secara internal. Hasil yang didapatkan satu UMKM akan berbeda dengan UMKM lain, sesuai pengembangan literasi informasi yang dilakukan. Untuk itu, motivasi internal SDM perlu dibangun dan dijaga. Penggerak UMKM harus memiliki motivasi dalam mendapatkan dan menggunakan informasi yang tepat guna melalui dukungan fasilitas yang mudah digunakan dan lingkungan kerja yang konstruktif. Adapun kondisi sebaliknya bila UMKM belum menyediakan fasilitas dan belum ada pelatihan maka akan menurunkan kualitas lingkungan kerja sehingga SDM tidak memiliki motivasi bekerja.

Untuk itu, UMKM ini dapat dikembangkan dengan baik dengan memperhatikan pelbagai faktor pendukung agar mampu mendukung pengembangan UMKM secara maksimal (LPPI \& Bank Indonesia, 2015). Salah satunya melalui faktor tenaga kerja. Di mana penggerak UMKM selama ini menghadapi beberapa kendala, seperti rendahnya

pengetahuan

dan

keterampilan, rendahnya motivasi, kurangnya disiplin, rendahnya produktivitas, dan tenaga kerja belum dibayar secara memadai.

Berdasarkan keseluruhan penjelasan di atas, dapat disimpulkan bahwa pemanfaatan literasi informasi mengalami perkembangan seiring waktu perkembangan teknologi informasi dan komunikasi. Hal ini akan memengaruhi masyarakat pada sektor bisnis atau penggerak UMKM. Perubahan secara signifikan ada karena realitas virtual yang berkembang. Selain itu, terjadinya perkembangan pemanfaatan big data dalam desain produk, proses produksi, dan pemasaran produk. Oleh karena itu, nilai informasi yang digunakan secara tepat sangat penting bagi penggerak UMKM khususnya di Kota Malang.

\section{SIMPULAN}

Penggerak UMKM Kota Malang menggunakan literasi informasi yang dikelompokkan sesuai kendala yang dihadapi secara internal dan eksternal. Kendala internal yakni modal, SDM, sarana dan prasarana sedangkan kendala eksternal yakni peran pemerintah, komunitas, dan respons konsumen. Sesuai dua faktor ini, kebutuhan informasi penggerak UMKM mengerucut pada informasi tentang desain produk, proses produksi, dan pemasaran. Adapun strategi pengembangan UMKM terkait literasi informasi dapat dilakukan melalui penguasaan beberapa kemampuan. Penggerak UMKM dapat melakukan identifikasi masalah dan memiliki solusi sebagai pemecahan masalah. Selain itu, penggerak UMKM dapat memanfaatkan informasi sebagai solusi awal dalam pelbagai bentuk, di antaranya 
kemampuan penggunaan teknologi dalam mengakses informasi, kemampuan mencari, memilah, dan memilih informasi tepat guna, dan kemampuan mengimplementasikan informasi. Penggerak UMKM pun dapat meningkatkan kemampuan dalam pengambilan keputusan, meningkatkan kinerja dalam hal desain produk, proses produksi, dan pemasaran produk. Model strategi pengembangan UMKM menggunakan literasi informasi diharapkan dapat diimplementasikan secara bertahap pada pihak ketiga. Hal ini diperlukan untuk menjaga kualitas dari proses perbaikan kualitas SDM. Pelaksanaan penelitian ini tentu masih jauh dari sempurna. Peneliti merasa perlu mengembangkan penelitian seperti penggunaan metode campuran kualitatif dan kuantitatif dengan fokus yang sama melalui uji model atau evaluasi pengoptimalan SDM. Peneliti dengan melakukan hal tersebut, diharapkan dapat mengembangkan model literasi informasi pada UMKM dan membawa manfaat optimal baik perkembangan konsep dan manfaat praktis bagi penggerak UMKM.

\section{DAFTAR PUSTAKA}

Adawiyah, W. R. (2011). Faktor penghambat pertumbuhan Usaha Mikro Kecil Menengah (UMKM): Studi di Kabupaten Banyumas. JpfebUNSOED: Journal and Proceeding, 1(1), 1-18. Retrieved from http://jp.feb.unsoed.ac.id/index.php /sca-1/article/viewFile/134/139

Agustien, Y. M., Prijana, \& Yanto, A. (2019). Relasi kemampuan literasi jaringan dengan manajemen privasi pelajar SMA Negeri 1 Sumedang. Pustakaloka, 11(1), 18-35.

https://doi.org/10.21154/pustakalok a.v11i1.1540

Anggraeni, F. D., Hardjanto, I., \& Hayat, A. (2013). Pengembangan Usaha Mikro, Kecil, dan Menengah (UMKM) melalui fasilitasi pihak eksternal dan potensi internal: Studi kasus pada kelompok usaha "Emping Jagung" di Kelurahan Pandanwangi Kecamatan Blimbing, Kota Malang. Jurnal Administrasi Publik, 1(6), 1286-1295. Retrieved from

http://administrasipublik.studentjou rnal.ub.ac.id/index.php/jap/article/ view/195/175

Aribawa, D. (2016). Pengaruh literasi keuangan terhadap kinerja dan keberlangsungan UMKM di Jawa Tengah. Jurnal Siasat Bisnis, 20(1), 113.

https://doi.org/10.20885/jsb.vol20.is s1.art1

Hapsari, I. M. (2014). Identifikasi berbagai permasalahan yang dihadapi oleh UKM dan peninjauan kembali regulasi UKM sebagai langkah awal revitalisasi UKM. Permana, 5(2), 43-47. Retrieved from http://ejournal.upstegal.ac.id/index.php/per /article/view/366

Indah, A. T. (2017). Pengaruh keterampilan teknologi terhadap produktivitas pada Subbagian Evaluasi dan Pengembangan SDM Dirjen Perhubungan Udara. Widya Cipta: Jurnal Sekretari Dan Manajemen, 1(2), 105-110.

https:/ / doi.org/10.31294/WIDYACI PTA.V1I2.1974

Irawan, M. R. N. (2017). Analisis SWOT untuk menentukan strategi kompetitif pada Pd. Bpr. Bank Daerah Lamongan. Jurnal Ekonika: Jurnal Ekonomi Universitas Kadiri, 2(1), 40-56. https:/ / doi.org/10.30737/ekonika.v2i 


\subsection{7}

Jordana, T. A., \& Suwarto, D. H. (2017). Pemetaan gerakan literasi digital di lingkup Universitas Negeri Yogyakarta. INFORMASI, 47(2), 167180.

https:// doi.org/10.21831/informasi.v 47i2.15735

LPPI \& Bank Indonesia. (2015). Profil bisnis usaha mikro, kecil dan menengah (UMKM). Bank Indonesia. Retrieved from

https:// webcache.googleusercontent. com/search?q=cache:rWDX6BYFb94J: https://www.bi.go.id/id/umkm/pe nelitian/nasional/kajian/Documents /Profil\%2520Bisnis\%2520UMKM.pdf $+\& \mathrm{~cd}=1 \& \mathrm{chl}=\mathrm{id} \& \mathrm{ct}=\mathrm{clnk} \& \mathrm{gl}=\mathrm{id}$

Mansyur, M., Rahamma, T., \& Fatima, J. M. (2013). Kemampuan literasi media visual siswa dan keberhasilan pembelajaran Teknologi Informasi dan Komunikasi (TIK) di SMP Negeri 11 Pare-Pare. Jurnal Komunikasi KAREBA，2(4), 379-385. Retrieved from

https://journal.unhas.ac.id/index.ph p/kareba/article/view/343/202

Muntashir. (2016). Standar kompetensi literasi informasi mahasiswa ilmu perpustakaan pada perguruan tinggi agama Islam. JIPI: Jurnal Ilmu Perpustakaan Dan Informasi, 1(1), 102124. Retrieved from

http://jurnal.uinsu.ac.id/index.php/j ipi/article/view/194/139

Muzakki, M. H., Susilo, H., \& Yuniarto, S. R. (2016). Pengaruh penggunaan teknologi informasi terhadap kinerja karyawan: Studi pada karyawan PT. Telkom Pusat Divisi Regional V Surabaya. Jurnal Administrasi Bisnis, 39(2), 169-175. Retrieved from http:/ /administrasibisnis.studentjour nal.ub.ac.id/index.php/jab/article/vi ew/1573/1955

Neuman, W. L. (2014). Social research methods: Qualitative and quantitative approaches (7th editio). England: Pearson Education Limited. Retrieved from

http:/ / letrunghieutvu.yolasite.com/r esources/w-lawrence-neuman-socialresearch-methods_-qualitative-andquantitative-approaches-pearsoneducation-limited-2013.pdf

Nurjanah, E., Rusmana, A., \& Yanto, A. (2017). Hubungan literasi digital dengan kualitas penggunaan eresources. Lentera Pustaka, 3(2), 117140. Retrieved from

https:/ / ejournal.undip.ac.id/index.p hp/lpustaka/article/view/16737/121 74

Undang-Undang Republik Indonesia Nomor 9 Tahun 1995 Tentang Usaha Kecil. 26 Desember 1995. Lembaran Negara Republik Indonesia Tahun 1995 Nomor 74. Jakarta. Retrieved from

https://www.bphn.go.id/data/docu ments/95uu009.pdf

Undang-Undang Republik Indonesia Nomor 11 Tahun 2009 Tentang Kesejahteraan Sosial. 16 Januari 2009. Lembaran Negara Republik Indonesia Tahun 2009 Nomor 12. Jakarta. Retrieved from

https://peraturan.bpk.go.id/Home/

Details/38601/uu-no-11-tahun-2009

Rahmadani, A., Hakim, L., \& Setiawati, B. (2019). Pengaruh pemberdayaan usaha kecil dan menengah terhadap pembangunan ekonomi masyarakat Kecamatan Wara Kota Palopo. Jurnal Administrasi Publik, 5(2), 244-261. Retrieved from

https://journal.unismuh.ac.id/index. 
php/kolaborasi/article/view/2313/1 829

Risnawati, N. (2018). Profil UMK, permasalahan dan upaya pemberdayaannya di Kabupaten Sumedang. Coopetition: Jurnal Ilmiah Manajemen, 9(1), 13-30. Retrieved from

https://ikopin.ac.id/jurnal/index.ph $\mathrm{p} /$ coopetition/article/view/44/45

Rumbianingrum, W., \& Wijayangka, C. (2018). Pengaruh literasi keuangan terhadap pengelolaan keuangan UMKM. ALMANA: Jurnal Manajemen Dan Bisnis, 2(3), 156-164. Retrieved from

http://journalfeb.unla.ac.id/index.ph $\mathrm{p} /$ almana/article/view/162/352

Sarfiah, S. N., Atmaja, H. E., \& Verawati, D. M. (2019). UMKM sebagai pilar membangun ekonomi bangsa. Jurnal REP: Riset Ekonomi Pembangunan, 4(2), 137-146. Retrieved from https://jurnal.untidar.ac.id/index.ph p/REP/article/view/1952/pdf_1

Setiawan, A. H. (2010). Analisis penyerapan tenaga kerja pada sektor Usaha Kecil dan Menengah (UKM) di Kota Semarang. JEJAK: Jurnal Ekonomi Dan Kebijakan, 3(1), 40-47. Retrieved from

https://journal.unnes.ac.id/nju/index .php/jejak/article/view/4663/3875

Ukkas, I. (2017). Faktor-faktor yang mempengaruhi produktivitas tenaga kerja industri kecil Kota Palopo. KELOLA: Journal of Islamic Education Management, 2(2), 187-200.

http://dx.doi.org/10.24256/kelola.v2 i2.440

Yusuf, M. (2016). Pengaruh pemanfaatan teknologi informasi dan kualitas sumber daya manusia terhadap keterandalan dan ketepatwaktuan. Jurnal Akuntansi Dan Pembangunan (JAKTABANGUN) STIE Lhokseumawe, 2(1), 149-172. Retrieved from https://ejurnalstielhokseumawe.com /ojs3/index.php/jaktabangun/article /view/12/11 


\section{DAFTAR GAMBAR}

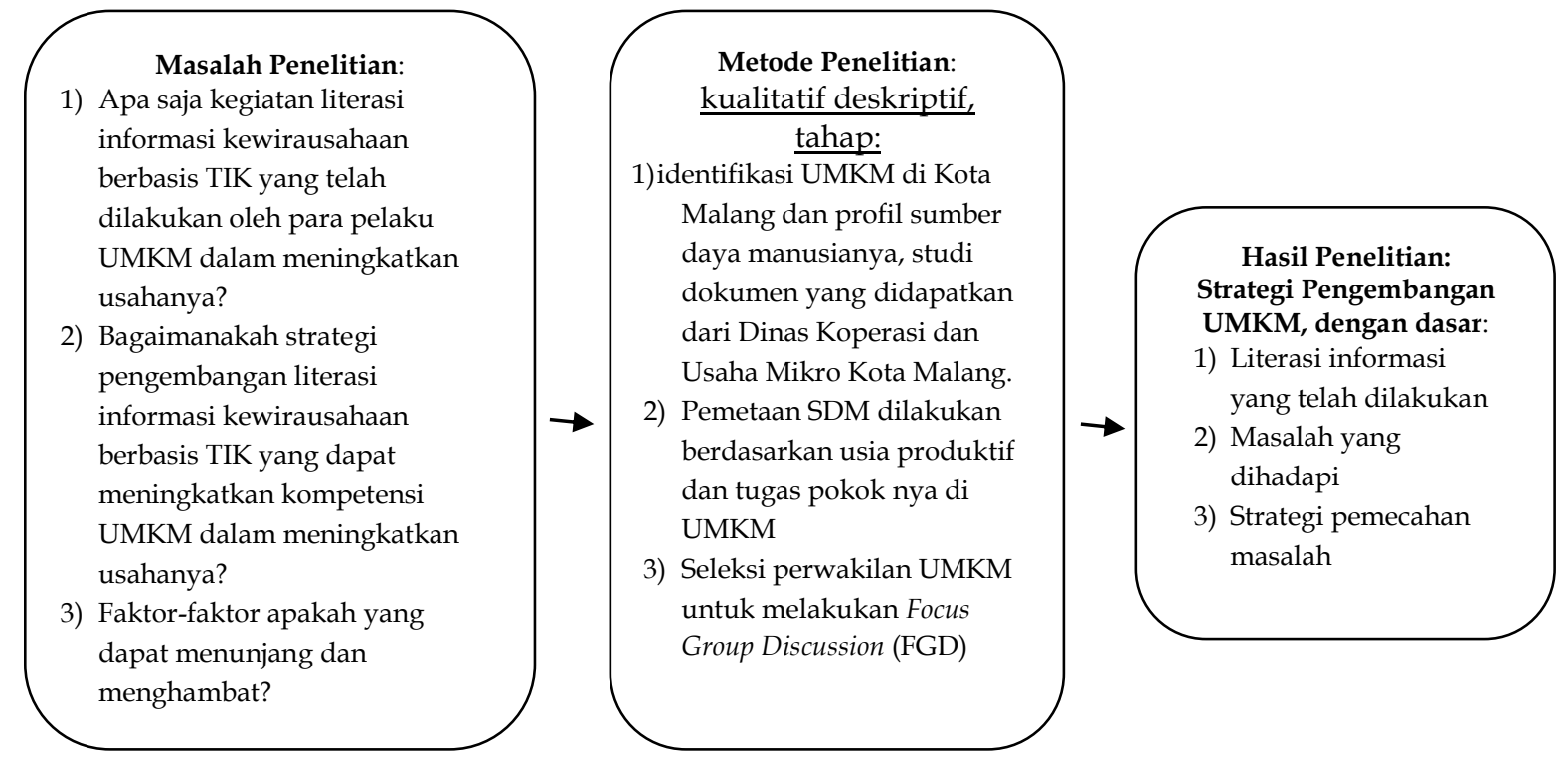

Gambar 1. Alur analisis

Sumber: Hasil analisis penulis, 2019

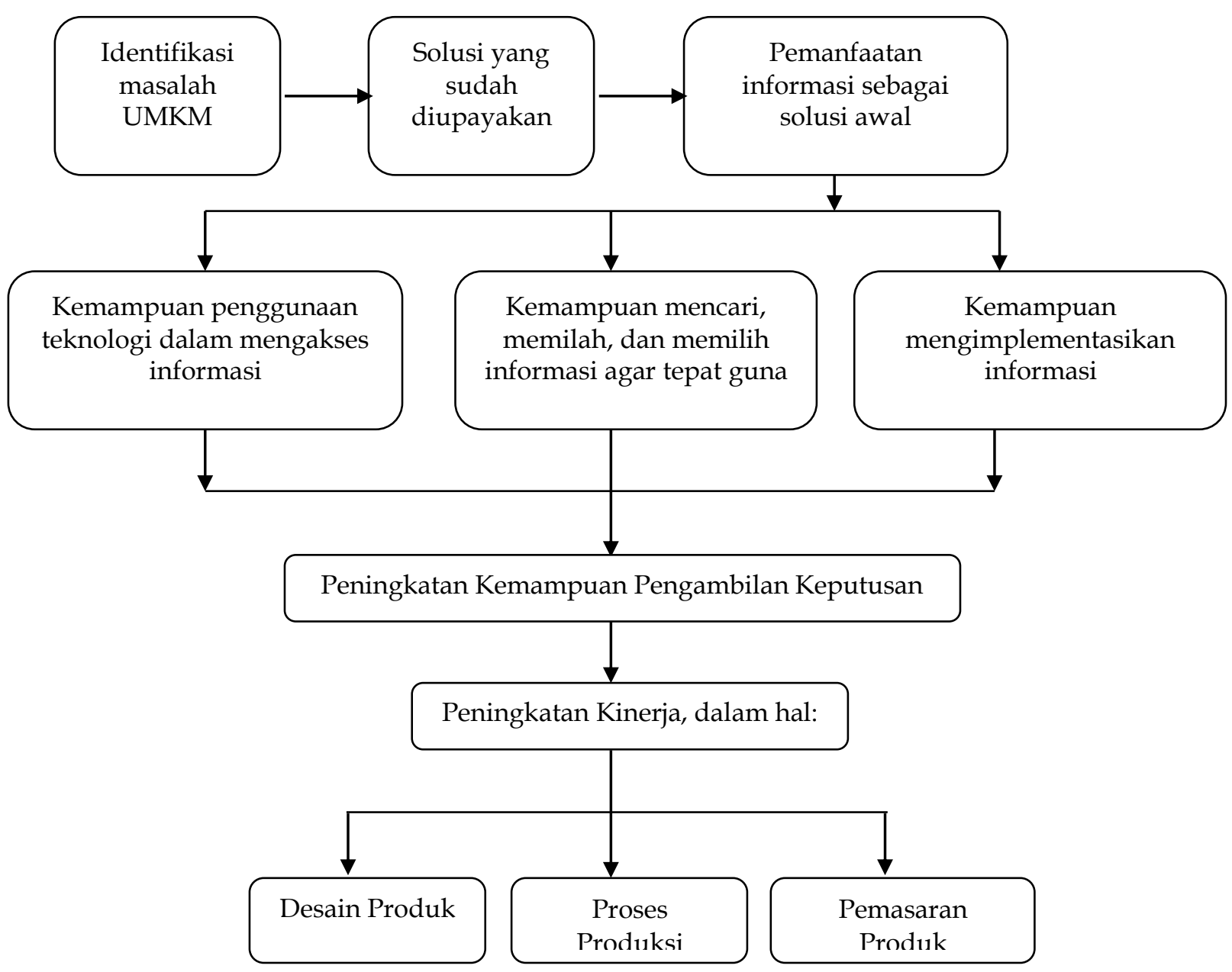

Gambar 2. Model strategi pengembangan UMKM dengan literasi informasi Sumber: Hasil analisis data, 2019 